\title{
Marmot Creek Experimental Watershed Study
}

\author{
by Richard Rothwell1', Graham Hillman² and John W. Pomeroy ${ }^{3 *}$
}

\section{ABSTRACT}

The origins and results of the scientific experiments in Marmot Creek Experimental Watershed, now the Marmot Creek Research Basin, over more than 50 years are reviewed. Marmot Creek was established to better understand how forest manipulations could be used to manage streamflow hydrographs and was actively manipulated in the 1970s and 1980s. While small forest clearings were shown to increase snow accumulation consistently, the impacts on melt rates depended on clearing size, slope and aspect. As a result, clearing treatments whether through large cutblocks or small clearings had modest impacts on the hydrograph timing and variability and only local impacts on streamflow volume. Changes in climate are primarily manifested as warming which has substantially reduced snowpacks at low elevations. These climate changes have not been evident in hydrograph change and there is no trend to volumes or timing of streamflow over the last 50 years. Overall the basin shows remarkable resiliency to climate and land use change due to its wide range of elevations, slopes, snow environments and sub-surface storage. The basin has become a hydrological process observatory where multi-scale models are developed and evaluated for operation over larger areas. It has served an invaluable role for this and the scientific results from Marmot Creek have supported the development of global climate models and hydrological models that are now applied throughout the world.

\section{RÉSUMÉ}

Cet article passe en revue les origines et les résultats de quelque 50 années de travaux de recherche effectués dans le bassin versant expérimental de Marmot Creek, appelé maintenant Bassin de recherche Marmot Creek. Marmot Creek a été créé afin de mieux comprendre comment utiliser les interventions forestières pour gérer les hydrogrammes de débit et a subi plusieurs interventions dans les années 1970 et 1980. Même s'il est connu que les petites éclaircies forestières augmentent systématiquement l'accumulation de la neige, leur effet sur la vitesse de fonte dépendait de la superficie de léclaircie, de sa pente et de sa forme. Les traitements par éclaircie, qu'ils prennent la forme de grands blocs ou de petites troués, n’ont donc eu qu’un effet limité sur la chronologie et la variabilité des hydrogrammes du débit et un effet localisé sur son volume. Ces modifications du climat se sont principalement manifestées par un réchauffement qui réduit considérablement l'accumulation de neige sur les terrains peu élevés. Ces changements du climat ne se traduisent pas par des changements dans les hydrogrammes et il n'y a pas de tendance manifeste dans les volumes ou la chronologie de lécoulement au cours des 50 dernières années. Dans son ensemble, le site démontre une résilience remarquable aux changements de climat et d’utilisation du territoire en raison de sa vaste gamme d’altitudes, de pentes, denvironnements neigeux et de réserves souterraines. Le site est devenu un observatoire des processus hydrologiques servant à concevoir et évaluer des modèles multiéchelles destinés à des sites plus étendus. Il a joué un rôle déterminant dans ce cas précis, et les résultats scientifiques obtenus à Marmot Creek ont servi à élaborer des modèles climatiques mondiaux et des modèles hydrologiques qui sont maintenant en usage partout dans le monde.

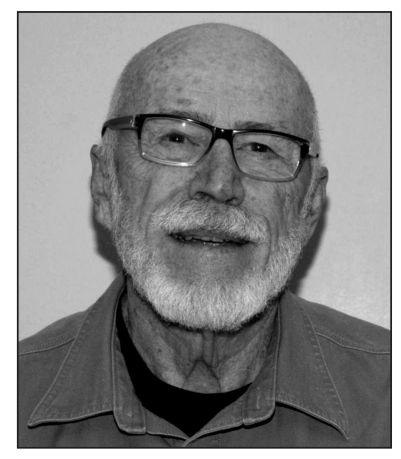

Richard Rothwell

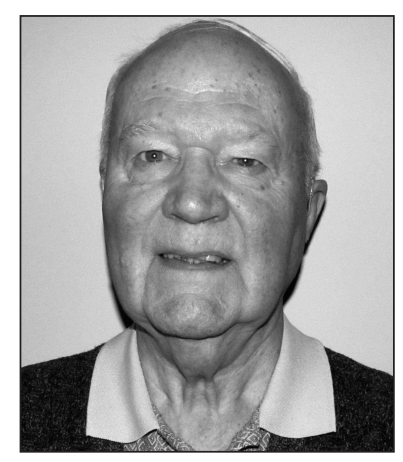

Graham Hillman

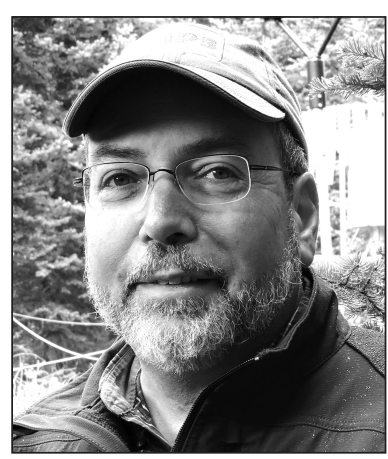

John W. Pomeroy

\footnotetext{
${ }_{1}^{1}$ Department of Renewable Resources, University of Alberta, Edmonton, Alberta

${ }^{2}$ Natural Resources Canada, Canadian Forest Service, Northern Forestry Centre, Edmonton, Alberta

${ }^{3}$ Centre for Hydrology, University of Saskatchewan, Saskatoon, Saskatchewan

*corresponding author's e-mail: john.pomeroy@usask.ca
} 


\section{Introduction}

The Marmot Creek Experimental Watershed was one of the earliest if not the first, long-term paired-basin study in Canada designed to assess the effects of forest cover manipulation on water flows. The project resulted from joint federalprovincial legislation in 1947 that created the Eastern Rockies Forest Conservation Board (ERCB) to implement watershed management practices and research to conserve and protect the Saskatchewan River headwaters.

The Marmot Creek Experimental Watershed was established in 1961-1962 to carry out forest cover manipulation treatments in subalpine spruce-fir forests with the objective to increase water yield and late season flows (Jeffery 1965). Marmot Creek was a collaborative project involving the following provincial and federal agencies: Alberta Forest Service (currently Alberta Agriculture and Forestry), Water Survey of Canada, Meteorological Branch of Transport Canada (currently Meteorological Service of Canada, Environment Canada), Research Council of Alberta, and the Department of Fisheries and Forestry (currently Canadian Forest Service).

Between 1985 and 1987 the Nakiska Ski Resort was built in the basin adjacent to Marmot Creek basin and opened for the 1986-1987 ski season. Some of the ski runs intruded into one of the Marmot Creek sub-basins (Twin Creek) and as a result, hydrometric stations and meteorological stations in the three sub-basins of Marmot Creek basin were discontinued after 1986. However, flow measurements were continued by Water Survey of Canada at the main-stem weir and groundwater measurements continued by the Government of Alberta.
In 2004, the basin was reactivated by the University of Saskatchewan, University of Calgary, and Environment Canada-since then it has supported a wide variety of research in process hydrology, snow hydrology, climatology, ecohydrology, and hydrological modeling which has provided critical data underpinning the next generation of models and supporting forest-management strategies. The characteristics and instrumentation at Marmot Creek over the years are shown in Table 1 and Fig. 1; Fig. 2 shows the overview of the basin and a map of its sub-basins and treatments.

\section{Research Studies 1962-1986: Treatments}

A paired-basin study design was used to evaluate the hydrologic effects of forest cover removal on streamflow in Marmot. Two major forest cover treatments were imposed on Marmot Creek Basin between 1962 and 1986. In each case results from treated areas were compared with those from Middle Creek, the control sub-basin. For most of the period, annual snow surveys were conducted in spring on the three sub-basins to determine the maximum snowpack prior to the spring runoff.

The first treatment, a "commercial" forest harvest, occurred in Cabin Creek between July and October 1974the objectives were to evaluate the effects on streamflow and sediment yield. Logging haul roads were constructed prior to the harvest in 1971-1972 with the intent to minimize the effects of road construction on sediment yields in the creek. In 1974, six blocks (45 ha), representing 50\% of the forested area in the sub-basin (21\% of the entire Cabin Creek subbasin), were clear-cut. Regression and covariance analysis

Table 1. Marmot Creek Watershed location, characteristics and measurements

\begin{tabular}{ll}
\hline Location (descriptive) & $\mathbf{9 3 ~} \mathbf{~ k m}$ west of Calgary AB in the Kananaskis Valley \\
\hline Location (geographic) & Latitude N $50^{\circ} 57^{\prime} 01^{\prime \prime} \mathrm{W} 115^{\circ} 09^{\prime} 01^{\prime \prime}$ \\
Watershed area & $\begin{array}{l}\text { Marmot Creek is } 9.4 \mathrm{~km}^{2} \text { in area with three sub-basins: Twin Basin }\left(2.79 \mathrm{~km}^{2}\right), \mathrm{Middle}^{2} \text { Basin }(2.94 \\
\left.\mathrm{km}^{2}\right), \text { and Cabin Creek }\left(2.35 \mathrm{~km}^{2}\right)\end{array}$
\end{tabular}

Elevation

Vegetation

Precipitation

Runoff

Hydrometric records (Source: Water Survey of Canada)

Temperature

Variables measured (1962-1986)

Variables measured (2004-2016)

\section{$1700-2825 \mathrm{~m}$}

Lodgepole pine, white spruce, Engelmann spruce, Alpine larch, Subalpine fir and aspen (Fig. 2)

$660 \mathrm{~mm}$ low elevations - $1140 \mathrm{~mm}$ upper elevations (alpine zone)

Mean annual: $310 \mathrm{~mm}$

Marmot Main Stem: 1962-2009

Twin Creek: 1963-1986

Middle Fork:1964-1986

Cabin Creek: 1963-1986

Mean annual $3.5^{\circ} \mathrm{C}$ (mean monthly temperatures: $-6^{\circ} \mathrm{C}$ winter to $13^{\circ} \mathrm{C}$ summer)

Streamflow, precipitation (rainfall and snow), patterns of snow distribution, water and energy budget/balance studies, basin soil survey and mapping, vegetation survey and mapping, and groundwater monitoring. See reference listings to source data.

Streamflow, snowfall, rainfall, soil moisture, groundwater levels, snow depth and density, solar and longwave radiation, vegetation structure, snow chemistry 


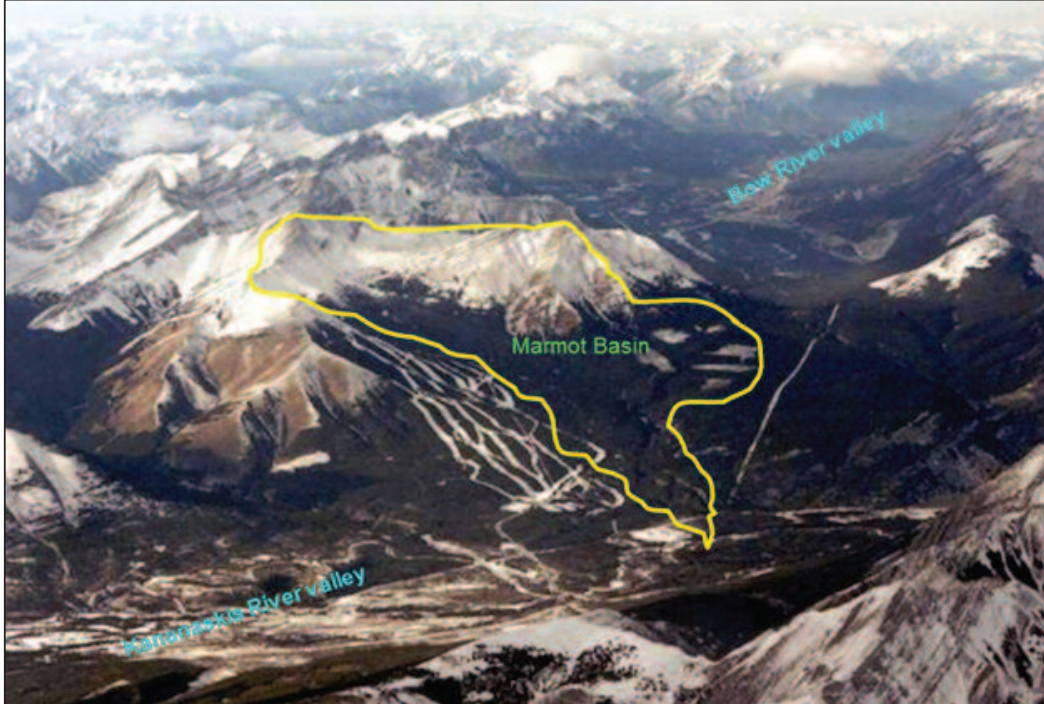

Fig. 1. Aerial view of Marmot Creek Experimental Watershed (Courtesy Centre for Hydrology, University of Saskatchewan)

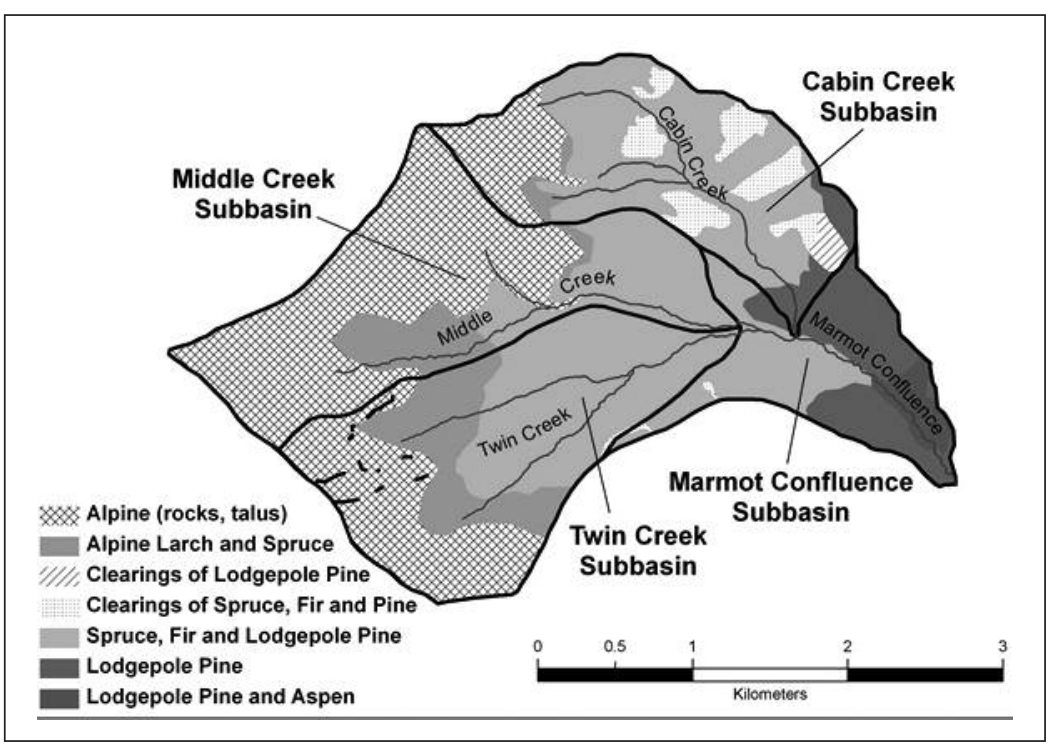

Fig. 2. Marmot Creek Watershed showing sub-basins, streams, forest cover types, and harvest blocks in Cabin Creek and circular openings in Twin Creek.

(Courtesy Centre for Hydrology, University of Saskatchewan).

were used to determine the effects of cutting on Cabin Creek streamflow. The treatment produced an increase in annual water yield of $35.7 \mathrm{dam}^{3}$ or $6 \%$ greater than predicted if left uncut. There were no increases in sediment concentrations that could be attributed to roads or logging.

The purpose of the second treatment, implemented on Twin Creek sub-basin, was to prolong recession flow from snowmelt and/or delay the time to peak runoff. This treatment took the form of a "honeycomb" pattern with about 3000 small circular openings ( $12.2 \mathrm{~m}$ to $18.3 \mathrm{~m}$ in diameter) cut in the forest. Approximately 62 ha or $24 \%$ of Twin Creek sub-basin were cleared between 1977 and 1979. It had been ascertained in a related study (Golding and Swanson 1986) that openings with diameters equal to the height of the surrounding trees captured the most snow while retaining it the longest in the spring.

In March 1980, 1981 and 1982 snow accumulation in the clearings was substantially greater than in the surrounding forest but there was no difference between the actual and predicted snow accumulation for the entire sub-basin.

Later analyses of the pre- and post-treatment streamflow by Harder et al. (2015) showed that after treatment, there was a trend for earlier and more variable streamflow and decreased peak flow at Cabin Creek, and less variable flow at Twin Creek when compared to the Middle Creek control. These results are consistent with increased snow accumulation in the clearings and varying melt rates with more prolonged melt for smaller clearings, particularly those facing north (Ellis et al. 2013). These differences did not translate into detectable impacts at the Marmot Creek basin scale (Harder et al. 2015).

\section{Important Scientific Advancement: 1962-1986}

Forest harvesting in Cabin Creek confirmed that increases in water yield in high elevation Canadian Rocky Mountain forests may occur following forest harvesting and are similar in magnitude to those reported in the United States and elsewhere in Alberta. Increased water yield in Cabin Creek was attributed to decreased evapotranspiration and increased snow accumulation in harvest blocks.

Observations of snow accumulation and ablation in Marmot (Golding and Swanson 1986) generated allied studies elsewhere that further described relationships between forest canopy gaps and snowpack retention (Berry and Rothwell 1992, Bernier and Swanson 1993). In some forested environments, circular forest openings/gaps of 2-3 tree heights are optimal for enhancing snow accumulation and delaying snow ablation (Golding and Swanson 1978).

\section{Research Studies 2004-2013}

Research from 2004 focused on cold regions hydrological processes and the development of improved hydrological models that could assess the changes in climate and land use that had occurred in Marmot Creek and other forested Canadian Rockies watersheds. Research on precipitation has provided a new method to calculate the transition from snowfall to rainfall using the psychrometric relationship and standard meteorological data (Harder and Pomeroy 2013). Research on solar radiation has improved calculation procedures for terrain shading and shown the importance of considering ter- 
rain shading in estimating alpine snowmelt (Marsh et al. 2012). New methods to estimate solar radiation from air temperature fluctuations have also proved promising (Shook and Pomeroy 2011). Research on turbulent transfer to snow has shown the difficulty in applying stability corrections in mountain valleys due to advected turbulent bursts and the need to consider turbulence characteristics in estimating mountain snowmelt (Helgason and Pomeroy 2012).

Forest canopy radiation transfer studies resulted in a new algorithm for shortwave radiation extinction in needleleaf canopies on slopes (Ellis and Pomeroy 2007). Measurements of snow interception and sublimation in spruce canopies and comparative snow surveys in forests and clearings established that sublimation of intercepted snow can ablate up to $60 \%$ of the seasonal snowfall from mid elevation sites in Marmot Creek (Ellis et al. 2010).

Observations of snowmelt on slopes showed the importance of forest density in moderating differences in incoming short and longwave radiation (Ellis et al. 2011). Model development based on these studies included short and longwave radiation under canopies, turbulent transfer under canopies and the interception, unloading and sublimation of snow in forest canopies. Model results showed that slope and aspect are not important for melt under forest canopies but are extremely important for forest clearings (Ellis et al. 2013).

In the alpine zone around Fisera Ridge, studies of blowing snow transport and sublimation and snowmelt on slopes were conducted. MacDonald et al. (2010) found that 20\% of alpine seasonal snowfall sublimated from blowing snow and that snow was almost completely eroded from windblown slopes, causing deposition on lee slopes to be more than double snowfall. Accumulation of snow in the forest edge at tree line was found to be the highest in Marmot Creek. DeBeer and Pomeroy $(2009,2010)$ report the distributions of snow water equivalent (SWE) can be described/modeled by lognormal distributions when stratified by terrain classes (i.e., hydrologic response units). The use of effective or basin average parameters to model snow cover disappearance results in large errors. They showed that snowpack cold content caused a spatial variation in melt rate where shallow snow melted earlier than deeper snow under similar energy inputs, and that this was an important factor in calculating snowmelt runoff from the Mt. Allan cirque sub-basin.

The Cold Regions Hydrological Model (CRHM) was developed using these and other studies in Marmot Creek and used to describe the hydrology of the basin using physically based calculations of blowing and intercepted snow, snow sublimation, melt, infiltration into frozen soils, evaporation and soil physics representations (Pomeroy et al. 2009, 2012; Fang et al. 2013). Perturbations of the model showed that forest disturbance impacts on snowpack were much greater than on streamflow because of the desynchronization of melt caused by forest removal in Marmot Creek (Pomeroy et al. 2012). Nevertheless, substantial increases in peak flow were simulated when a large portion of the forest canopy was removed. However, pine beetle kill of lodgepole pine had an insignificant impact on streamflow because it occurs at low elevations where precipitation is low and runoff generation is small. The most recent hydrological model can simulate the snowpack, soil moisture, groundwater and streamflow in Marmot Creek without calibration of parameters due to its reliance on the large number of scientific findings in the basin over 50 years (Fang et al. 2013).

Climate change impacts and resiliency were examined by Harder et al. (2015) in a study surveying the entire observational record of Marmot Creek. The 52 years of observations showed increases in low elevation air temperature, multiple day and spring precipitation, interannual variability of precipitation, and high elevation groundwater levels. Peak seasonal snow accumulation and low elevation groundwater levels have decreased. Despite these substantial hydrometeorological and groundwater changes, streamflow volume, timing of peak, and magnitude of the peak did not change. Streamflow volumes were also insensitive to forest cover changes and teleconnections. The June 2013 flood was unprecedented in the period of record, and the basin significantly moderated the hydrological response to the extreme precipitation. The 2013 storm precipitation depth was $65 \%$ greater than the next highest storm total over 51 years; however, the 2013 peak streamflow was only $32 \%$ greater than the next highest peak flow recorded (Pomeroy et al., 2015).

\section{Management/Operational Results}

The Marmot Creek Watershed was established in 1947 with the creation of the Alberta East Slopes Forest Conservation Board (ERCB). The mandate of the ERCB was the conservation, development, maintenance and management of the forests in the eastern slopes watershed with a view to obtaining the greatest possible flow of water in the Saskatchewan River and its tributaries. Research at Marmot today still continues to study the hydrology of snow dominated subalpine watersheds.

Swanson et al. (1986) indicate that it is technically possible to use timber harvesting to increase water yield from Alberta's east slopes watersheds of the Saskatchewan River. They recommend cut block dimensions of five tree heights wide (assuming an average tree height of $20 \mathrm{~m}$ ) or one hectare to be optimal to generate water yield increases in Alberta subalpine and foothill forests. Harvesting one ha blocks however, is not economically viable for commercial forest harvesting. Furthermore, Ellis et al. (2013) report the honey-comb harvest pattern tested in Twin Creek was not effective in increasing water yield or in delaying peak flows because of differing effects on melt rate on south facing versus north facing slopes.

Larger cut blocks or harvesting in narrow blocks along a contour on north-facing aspects might be a compromise between increased water flows and commercial harvesting; there is evidence for increased streamflow from these treatments when simulated using the CRHM model (Pomeroy et al. 2012). Treatments like this might have results similar to those found in Fraser Creek in Colorado, where water yield increases were sustained for many years after harvesting (Alexander et al., 1985). Another question to be answered is: How to extrapolate small basin water yield increases to a landscape scale?

Although we cannot extrapolate the results of the Cabin Creek study to the larger landscape, we can get a rough idea of what might happen by considering the results of a study conducted near Hinton, which lies about $360 \mathrm{~km}$ northwest of Marmot Basin (Swanson and Hillman 1977). The study area is at a lower elevation than Marmot, receives less precipitation and is commercially logged (16-ha to 25-ha clear-cut 
strips or blocks). Paired watersheds (nine logged and nine untreated) distributed across a $7773 \mathrm{~km}^{2}$ forest management area were measured in 1973 and 1974. Results showed that there was a $27 \%$ greater water yield on the logged areas during the gauged season. On Marmot the increase in annual water yield was $6 \%$.

\section{References}

Alexander, R.R., C.A. Troendle, M.R. Kaufmann et al. 1985. The Fraser Experimental Forest, Colorado: Research program and published research 1937-1985. General Technical Report RM-118. Fort Collins, Colorado, USDA Forest Service, Rocky Mountain Forest and Range Experiment Station. $46 \mathrm{p}$.

Bernier, P. and R. Swanson. 1993. The influence of gap size on snow evaporation in the forests of the Alberta foothills. Can. J. Forest Res. 23(2): 239-244.

Berry, G.J. and R.L. Rothwell. 1992. Snow ablation in small forest openings in Southwest Alberta. Can. J. Forest Res. 22(9): 1326-1331, doi: $10.1139 / \mathrm{x} 92-176$.

DeBeer, C. and J.W Pomeroy. 2009. Modelling snowmelt and snow cover depletion in a small alpine cirque, Canadian Rocky Mountains. Hydrol. Processes 23(18): 2584-2599.

DeBeer, C. and J.W. Pomeroy. 2010. Simulation of the snowmelt runoff contributing area in a small alpine basin. Hydrol. Earth Syst. Sci. 14(7): 1205-1219.

Ellis, C.R. and J.W. Pomeroy. 2007. Estimating sub-canopy shortwave irradiance to melting snow on forested slopes. Hydrol. Processes 21: 2581-2593.

Ellis, C.R., J.W. Pomeroy and T.E. Link. 2013. Modelling increases in snowmelt yield and desynchronization resulting from forest gapthinning treatments in a northern mountain headwater basin. Water Resour. Res. 49: 1-14. doi: 10.1002/wrcr.20089.

Ellis, C.R., J.W. Pomeroy, T. Brown and J. MacDonald. 2010. Simulation of snow accumulation and melt in needle leaf forest environments. Hydrol. Earth Syst. Sci. 14 (6): 925-940.

Ellis, C.R., J.W. Pomeroy, R.L.H. Essery and T.E. Link. 2011. Observations of forest cover effects on radiation and snowmelt dynamics in the Canadian Rocky Mountains. Can. J. Forest Res. 41: 608-620, doi:10.1139/X10-227.

Fang, X., J.W. Pomeroy, C.R. Ellis, M.K. MacDonald, C.M. DeBeer and T. Brown. 2013. Multi-variable evaluation of hydrological model predictions for a headwater basin in the Canadian Rocky Mountains, Hydrol. Earth Syst. Sci. 17: 1635-1659, doi: 10.5194/hess-17-1635-2013.

Golding, D.L. and R.H. Swanson. 1978. Snow accumulation and melt in small forest openings in Alberta. Can. J. Forest Res. 8: $380-388$.
Golding, D.L. and R.H. Swanson. 1986. Snow distribution patterns in clearings and adjacent forest. Water Resour. Res. 22: 1931-1940.

Harder, P., J.W. Pomeroy and C.J. Westbrook. 2015. Hydrological resilience of a Canadian Rockies headwaters basin subject to changing climate, extreme weather and forest management. Hydrol. Processes, 29(18): 3905-3924.

Harder, P. and J.W. Pomeroy. 2013. Estimating precipitation phase using a psychrometric energy balance method. Hydrol. Processes 27(13): 1901-1914. doi: 10.1002/hyp.9799.

Helgason, W. and J.W. Pomeroy. 2012. Characteristics of the nearsurface boundary layer within a mountain valley during winter. J. Appl. Meteor. Climatol. 51: 583-597.

Jeffrey, W.W. 1965. Experimental watersheds in the Rocky Mountains, Alberta, Canada. Symposium of Budapest, Proceedings of the Symposium on Representative and Experimental Areas, 28 September-5 October 1965, Budapest, Hungary, pp. 502-521.

MacDonald, M.K., J.W. Pomeroy and A. Pietroniro. 2010. On the importance of sublimation to an alpine snow mass balance in the Canadian Rocky Mountains. Hydrol. Earth Syst. Sci. 14: 1401-1415, doi:10.5194/hess-14-1401-2010.

Marsh, C.B., J.W. Pomeroy and R.J. Spiteri. 2012. Implications of mountain shading on calculating energy for snowmelt using unstructured triangular meshes. Hydrol. Processes 26(12): 1767-1778, doi:10.1002/hyp.9329.

Pomeroy, J.W., R.E. Stewart and P.H. Whitfield. 2015. The 2013 flood event in the South Saskatchewan and Elk River basins: Causes, assessment and damages. Can. Water Resour. J., DOI:10.1080/ 07011784.2015.1089190.

Pomeroy, J.W., X. Fang and C. Ellis. 2012. Sensitivity of snowmelt hydrology in Marmot Creek, Alberta to forest cover disturbance. Hydrol. Processes 26(12): 1892-1905, doi:10.1002/hyp.9248.

Pomeroy, J.W., D. Marks, T. Link, C. Ellis, R. Essery, J. Hardy, A. Rowlands and R. Granger. 2009. The impact of coniferous forest temperatures on incoming longwave radiation to melting snow. Hydrol. Processes 23(17): 2513-2525, doi:10.1002/hyp.7325.

Shook, K.R. and J.W. Pomeroy. 2011. Synthesis of incoming shortwave radiation for hydrological simulation. Hydrol. Res. 46(2): 433-446.

Swanson R. H. and Hillman G. R. 1977. Predicted increased water yield after clear-cutting verified in west central Alberta. Inf. Rep. Nor-X-198, North. For. Res. Cent., Can. For. Serv., Edmonton AB Canada.

Swanson, R.H., D.L. Golding, R.L. Rothwell and P.Y. Bernier. 1986. Hydrologic effects of clear-cutting at Marmot Creek and Streeter Watersheds, Alberta. Inf. Rep. NOR-X0278. North. For. Cent., Can. For. Serv. 27 p. 